\title{
Range expansion of the invasive insect Greenidea (Trichosiphon) psidii (Hemiptera: Aphididae) in the Neotropical Region
}

\author{
M. P. Culik*, J. A. Ventura ${ }^{2}$ and D. dos S. Martins ${ }^{2}$
}

\begin{abstract}
Greenidea psidii is an invasive insect from Asia that feeds on a diverse variety of agriculturally and environmentally important plant species. As an essential component of research necessary for development of a better understanding of biodiversity and its conservation, this study documents a major recent expansion in range of G. psidii in the Neotropics to the region of the tropical restinga ecosystem of Brazil, where it was found infesting guava (Psidium guajava) and jabuticaba (Plinia cauliflora). A summary of information on the geographic distribution, host plants, identification, and potential natural enemies of G. psidii that may be useful for integrated management of this pest in the Neotropical Region and other areas where this invasive insect has recently become established and is likely to further spread is also provided.
\end{abstract}

Keywords: Biodiversity, Biogeography, Geographic distribution, Integrated pest management (IPM), Myrtaceae

\section{Background}

The insect Greenidea (Trichosiphum) psidii van der Goot (Hemiptera: Aphididae) is an invasive pest that feeds on ecologically and economically important plants of the family Myrtaceae such as guava (Psidium guajava), and has been recorded from plants in a diverse variety of other families (Halbert 2004; Pérez Hidalgo et al. 2009). Greenidea psidii is originally from Asia and has recently invaded many other areas such as the United States, Costa Rica, and Mexico (Halbert 2004; Pérez Hidalgo et al. 2009; Salas-Araiza et al. 2011) where it has become established and has caused concern as a pest of agriculturally valuable crops such as guava as well as environmentally important native species such as jabuticaba (Plinia cauliflora). G. psidii was recorded for the first time in Brazil in 2004 on guava in the State of Paraná, and subsequently observed in Santa Catarina and São Paulo on guava, and on Psidium cattleianum in Paraná (Lazzari et al. 2006). This study reports a major new expansion in

\footnotetext{
*Correspondence: markculik@hotmail.com

${ }^{1}$ Instituto Capixaba de Pesquisa, Assistência Técnica e Extensão Rural CRDR-CN, Rodovia BR 101 Norte, Km 151, C.P. 62, Linhares, Espírito Santo CEP 29915-140, Brazil

Full list of author information is available at the end of the article
}

range of G. psidii in the Neotropics to the region of the tropical restinga ecosystem (Lacerda et al. 1984), where this aphid was found feeding on guava and jabuticaba.

\section{Results and discussion}

Aphid specimens collected from a heavily infested guava and jabuticaba plants growing in Vitória, Espírito Santo in 2014 were identified as G. psidii. Collection data: G. psidii: Vitória, Espírito Santo, col. M. P. Culik, 23 July 2014, ex. guava (P. guajava); Vitória, Espírito Santo, col. A. do C. Carvalho, 20 November 2014, ex. jabuticaba ( $P$. cauliflora).

Greenidea psidii is originally from Asia and in that region it has been recorded from Bangladesh, China, India, Indonesia (Java, Sumatra), Japan, Nepal, Pakistan, Philippines, and Taiwan (Halbert 2004). Recently, this invasive insect has spread to North, Central and South America and in these regions it has been found in the United States, in the States of California and Florida (Halbert 2004), in Brazil, in the States of Paraná, Santa Catarina, and São Paulo (Lazzari et al. 2006), Costa Rica (Pérez Hidalgo et al. 2009), Mexico (Salas-Araiza et al. 2011), and Panama and Venezuela (Cermeli et al. 2012). As the distance of the locale of this record of G. psidii 
in Espírito Santo is more than $700 \mathrm{~km}$ from the locale of previous records of the species in South America [Curitiba and Morretes, Paraná; Penha, Santa Catarina; and São Paulo, São Paulo, Brazil (Lazzari et al. 2006)], this record of G. psidii documents a major new expansion in the distribution of this invasive pest in the Neotropics. This is the first record of G. psidii in the region of the tropical restinga ecosystem, and thus, this invasive insect now represents an additional new threat to the native biodiversity of this ecosystem (Culik et al. 2013, 2014).

Greenidea psidii is an aphid which feeds on a diverse variety of plant hosts by sucking their sap which may weaken and damage such plants. Hosts of G. psidii include species in at least seven plant families including P. guajava and other Myrtaceae (species of Callistemon, Eucalyptus, Eugenia, Melaleuca, Metrosideros, Plinia, Rhodomyrtus, Syzygium, and Tristania), as well as species of Glycosmis (Rutaceae), Engelhardtia (Juglandaceae), Ficus (Moraceae), Lagerstroemia (Lythraceae), Rhamnus (Rhamnaceae) and Scurrula (Loranthaceae) (Halbert 2004; Pérez Hidalgo et al. 2009). As a plant feeding invasive pest G. psidii is especially of concern because it threatens agriculturally important crops such as guava as well as environmentally important native species such as jabuticaba.

Most members of the aphid subfamily Greenideinae, including Greenidea, have long siphunculi with correspondingly long setae (Halbert 2004) and therefore G. psidii can be distinguished from other aphid species common in Brazil based on easily observed characters such as the long siphunculi. However, the species G. ficicola Takahashi is also present in Brazil and G. psidii may be distinguished from G. ficicola as described by Halbert (2004): G. ficicola apterae have reticulations covering most of the length of the siphunculi, and alatae have 17-21 rhinaria on antennal segment III, in a line and not crowded or touching each other; whereas, G. psidii apterae have reticulations only at the base of the siphunculi and the siphunculi are ornamented with irregularly spaced spinules, and alatae have 20-31 rhinaria, some crowded and not in line with the others, and often touching. Additional information concerning the identification of aphid species is found in Blackman (2016).

As an invasive species it is likely that G. psidii has entered Brazil without its native natural enemies (Blossey 2011). Thus, introduction of host-specific natural enemies of G. psidii from its area of origin (classical biological control) may be useful for control of the aphid in areas where natural enemies of the pest are not currently present. Starý et al. (2010) provided information on four parasitoids that have been recorded from G. psidii in India and Bangladesh (Table 1) that may be useful for classical biological control of this insect in areas where its natural enemies are not present or not effective in preventing

Table 1 Potential natural enemies of the invasive aphid G. psidii

\begin{tabular}{|c|c|c|}
\hline $\begin{array}{l}\text { Order: family } \\
\text { Species }\end{array}$ & Location of observation ${ }^{a}$ & Present in Brazil \\
\hline \multicolumn{3}{|l|}{ Neuroptera: Chrysopidae } \\
\hline Chrysoperla carnea (Stephens) & Mexico & No (de Freitas and Morales 2009) \\
\hline Chrysoperla comanche (Banks) & Mexico & No (de Freitas and Morales 2009) \\
\hline Chrysoperla exotera (Navás) & Mexico & No (de Freitas and Morales 2009) \\
\hline \multicolumn{3}{|l|}{ Coleoptera: Coccinellidae } \\
\hline Coccinella L. spp. & Mexico & Yes (CABI 2015) \\
\hline Cycloneda sanguinea (L.) & Mexico & Yes (González 2012) \\
\hline Harmonia axyridis (Pallas) & Mexico & Yes (González 2012) \\
\hline Hippodamia convergens Guerin-Meneville & Mexico & Yes (González 2012) \\
\hline Hyperaspis quadrioculata (Motschulsky) & Mexico & Not known \\
\hline Olla v-nigrum Mulsant & Mexico & Yes (González 2012) \\
\hline Scymnus Kugalann spp. & Mexico & Yes (González 2012) \\
\hline Stethorus Weise spp. & Mexico & Yes (González 2012) \\
\hline Zoglobra spp. & Mexico & Not known \\
\hline \multicolumn{3}{|l|}{ Hymenoptera: Braconidae } \\
\hline Archaphidus greenideae Stary \& Schlinger & Bangladesh & No (Starý et al. 2010) \\
\hline Binodoxys greenideae (Stary \& Harten) & Bangladesh & No (Starý et al. 2010) \\
\hline Binodoxys trichosiphae (Samanta \& Raychaudhuri) & India & No (Starý et al. 2010) \\
\hline Lipolexis oregmae (Gahan) & India & No (Starý et al. 2010) \\
\hline
\end{tabular}

${ }^{a}$ Reference source: Mexico, Salas-Araiza et al. (2011); Bangladesh, India, Starý et al. (2010) 
economically or environmentally damaging populations of the pest. In Mexico, Salas-Araiza et al. (2011) observed that three native Chysoperla (Neuroptera: Chrysopidae) predators fed readily on G. psidii and also noted nine species of coccinellids (Coleoptera: Coccinellidae) predators associated with the pest that may also contribute to control of this aphid (Table 1).

\section{Conclusions}

Increased knowledge of the occurrence and distribution of invasive pests such as G. psidii in the Neotropics is needed to inhibit dissemination of such pests to new areas in this region as well as to support research to reduce economically and environmentally harmful impacts of such organisms on crops and native biodiversity (Culik et al. 2013, 2014). Control of invasive insects such as G. psidii depends on integrated pest management (IPM) including biological control by native natural enemies of the pest if they are present, and introduction of host-specific natural enemies of the pest from its area of origin should be considered if native natural enemies are not effective in maintaining impacts of the pest below tolerable levels. Thus, additional research to determine the impacts and natural enemies of G. psidii in South America is needed to address potential negative economic and ecological impacts of this and similar invasive organisms in this region.

\section{Methods}

A guava plant in Vitória, Espírito Santo, heavily infested with aphids was observed in July 2014 and samples of infested leaves of the plant were collected for identification of the insects. Approximately 100 adults and nymphs from several leaves were preserved in alcohol (Entomology Collection of Incaper, Vitória). Specimens were mounted on slides and identified as G. psidii based on Halbert (2004). In November 2014 specimens collected from a heavily infested, potted jabuticaba plant growing approximately $1 \mathrm{~km}$ from the original collection site in Vitória, Espírito Santo, were also identified as G. psidii.

\section{Authors' contributions}

MPC collected and identified organisms studied in this research with support from JAV and DSM. All authors read and approved the final manuscript.

\section{Author details}

${ }^{1}$ Instituto Capixaba de Pesquisa, Assistência Técnica e Extensão Rural CRDR-CN, Rodovia BR 101 Norte, Km 151, C.P. 62, Linhares, Espírito Santo
CEP 29915-140, Brazil. ${ }^{2}$ Instituto Capixaba de Pesquisa, Assistência Técnica e Extensão Rural (Incaper), Rua Afonso Sarlo 160, Vitória, Espírito Santo CEP 29052-010, Brazil.

\section{Acknowledgements}

To the Instituto Capixaba de Pesquisa, Assistência Técnica e Extensão Rural (Incaper), Fundação de Amparo à Pesquisa e Inovação do Espírito Santo

(Fapes), and Conselho Nacional de Desenvolvimento Científico e Tecnológico (CNPq) for support and A. do C. Carvalho, for assistance.

\section{Competing interests}

The authors declare that they have no competing interests.

Received: 28 March 2016 Accepted: 1 June 2016

Published online: 16 June 2016

\section{References}

Blackman R (2016) Aphids on the world's plants. http://www.aphidsonworldsplants.info/. Accessed 3 May 2016

Blossey B (2011) Enemy release hypothesis. In: Simberloff D, Rejmánek M (eds) Encyclopedia of biological invasions. University of California Press, Berkeley, pp 193-196

CABI (2015) Coccinella septempunctata (seven-spot ladybird). CABI Invasive Species Compendium, Wallingford. http://www.cabi.org/isc/datasheet/11733. Accessed 13 April 2015

Cermeli M, Ortego J, Perozo J, Escalona E (2012) Presencia de Greenidea psidii (Hemiptera: Aphididae) en Venezuela. Entomotropica 27:37-40

Culik MP, Fornazier MJ, dos Martins DS, Zanuncio J Jr, Ventura JA, Peronti ALBG, Zanuncio JC (2013) The invasive mealybug Maconellicoccus hirsutus: lessons for its current range expansion in South America and invasive pest management in general. J Pest Sci 86:387-398

Culik MP, dos Martins DS, Ventura JA, Costa VA (2014) The invasive gall wasp Quadrastichus erythrinae (Hymenoptera: Eulophidae) in South America: is classical biological control needed? Biocontrol Sci Technol 24:971-975

de Freitas S, Morales AC (2009) Indicadores morfométricos em cabeças de espécies brasileiras de Chrysoperla (Neuroptera, Chrysopidae). Rev Bras Entomol 53:499-503

González G (2012) Coccinellidae de Brasil. http://www.coccinellidae.cl/paginasWebBra/Paginas/Coccinellidae_Bra_01.php. Accessed 13 Aug 2015

Halbert SE (2004) The genus Greenidea (Rhynchota:Aphididae) in the United States. Fla Entomol 87:159-163

Lacerda LD, Araujo DSD, Cerqueira R, Turcq B (1984) Restingas: origem, estrutura, processos. Universidade Federal Fluminense, Rio de Janeiro

Lazzari SMN, de Carvalho RCZ, Cardoso JT, Calado DC (2006) First record of Greenidea psidii van der Goot and comparison with Greenidea ficicola Takahashi (Hemiptera: Aphididae) in Brazil. Zootaxa 1235:63-68

Pérez Hidalgo N, Villalobos Muller W, Mier Durante MP (2009) Greenidea psidii (Hemiptera: Aphididae: Greenideinae) new invasive aphid in Costa Rica. Fla Entomol 92:396-398

Salas-Araiza MD, Jones RW, Peña-Velasco A, Martínez-Jaime OA, Salazar-Solís E (2011) Population dynamics of two species of Greenidea (Hemiptera: Aphididae) and their natural enemies on Psidium guajava (Myrtaceae) and Ficus benjamina (Moraceae) in central Mexico. Fla Entomol 94:396-398

Starý P, Rakhshani E, Havelka J, Tomanović Ž, Nikolas G, Kavallieratos NG, Sharkey M (2010) Review and key to the world parasitoids (Hymenoptera: Braconidae: Aphidiinae) of Greenideinae aphids (Hemiptera: Aphididae), including notes on invasive pest species. Ann Entomol Soc Am 103:307-321 